the Cimbrians of the Cimmerian Bosphorus, driven to the west of Europe by the Scythian invasion in the seventh century B.C. These Cymbrians had already had relations with the Greek world, for the Greeks had established colonies and introducer metals and the cultivation of the soil in Southern Russia before the arrival of the Scythians, and they may be regarded as the importers of the dialect from which the German languages arose. They were of the same race as the Neolithic blonds.

The Goths were driven away from the northern borders of the Black Sea by the Huns before the end of the fourth century; but though they remained during only two centuries, traces of their stay hąve been discovered.

The Alains, mentioned by authors in the first century A.D., were a blond people mixed with Medes, and possibly with the Scythian Massagetes. The Ossethes sprang from these Scythian Alains, who were driven into the Caucasus after the Gothic period by the pressure of the Huns. Thus the Ossethes are essentially Aryans and Europeans, despite the Iranian and Asiatic origin of their language, these originally blond Europeans, have been intimately mingled with Scythians, and later with other Caucasians, mostly browns and brachycephals. M. Kovalewsky states that among the Ossethes, when a bride enters for the first time her husband's house, she is greeted with "Prosperity! prosperity! nine boys and a girl with blue eyes." The latter wish could never arise amongst a brown population. In his work "Droit Coutumier Osséthien" (I 893), Kovalewsky details numerous customs which, as Zaborowski points out, abundantly confirm the essentially European and Aryan origin of this nation ; and the former author compares them with those of the Greeks of Homer, the Germans of Tacitus, and with the Romans, such, for example, as the cult of the hearth-fire, household arrangements, marriage ceremonies, and burial customs.

The Armenians, like the Ossethes, are a people with their original characters modified. They were also blond, at least in great part, and even now I I per cent. are blonds according to Chantre.

In the Hindu Kush there are many traces of a fair race, and Zaborowski enters into a comparison of the Kafirs with the Ossethes, which tends to show that they are closely related.

\section{THE HORN EXPEDITION TO CENTRAL AUSTRALIA.}

THE Report on the work of the Horn Scientific Expedition to Central Australia has now been completed. It is published in four parts, the first of which is devoted to the narrative and summary of scientific results, while the three remaining parts deal respectively with zoology, geology and botany, and anthropology. The zoological results were reviewed in NATURE a short time ago (vol. liv. p. 24I), and we propose to deal with the part on anthropology in a future issue. For the present we confine ourselves to summarising the knowiedge gained of the geology and botany of the region explored, prefacing the synopsis with a statement of the inception and objects of the expedition, and of the region traversed, this introductory matter being based upon the Narrative.

\section{Objects of the Expedition.}

Mr. W. A. Horn, who defrayed the cost of the expedition to Central Australia, and through whose generosity the Report has been publisherl, deserves the gratitude of men of science. The results which he has been the means of obtaining are most valuable contributions to the knowledge of the natural history of a little-known region; and by the accumulation of these facts, gained by direct observation, many perplexing questions will be elucidated. One of these questions is referred to by $\mathrm{Mr}$. Horn in a brief introduction to the Narrative. For some time the opinion has been held that when the Australian continent was submerged the elevated portions of the McDonnell Range in Central Australia existed as an island, and that consequently older forms of life might be found in the more inaccessible parts. The scientific exploration of this belt of country was, therefore, much desired by men of science, and when Mr. Horn expressed his intention to organise and equip an exploring party, the scheme was received with great favour. In order to secure the services of the best men in Australia, the Premiers of the principal colonies were asked to nominate scientific representatives. As a result, Prof. Baldwin Spencer, Mr. J. Alexander Watt, Prof. Ralph Tate, and Dr. Edward Stirling joined the expedition, and Mr. C. A. Winnecke was chosen as surveyor and meteorologist.

The objects of the expedition as set down in the articles under which the members started were :--The scientific examination of the country from Oodnadatta to the McDonnell Range; the col. lection of specimens illustrative of the fauna, flora, and geo. logical structure and mineralogical resources of that region, and the illustration by photography of any remarkable natural features of the country traversed; the securing of photographs of the aborigines in their primitive state, the collection of information as to their manners, customs, and language, and the reproduction of their mural paintings. The expedition started in Mav I894, and returned in August of the same year, burdened with the records and the photographic spoil of the region which the members went out to see.

\section{The McDonnell Ranges}

The McDonnell Ranges are in the very centre of Australia, they are barren and rugged in the extreme, rise to an altitude of nearly 5000 feet above sea-level, while the country surrounding them has an altitude of about 2000 feet, sloping away on every side towards the coast, I000 miles distant. The mountains are at the head of the river Finke, and for this region, including the valley of the Finke, the name of Larapintine has been adopted from the native name of the Finke, "Larapinta." It was over this area that most of the explorations were conducted.

The general editor of the Report on the work of the expedition is Prof. Baldwin Spencer, who is also the author of the Narrative. Without entering into too many details, Prof. Spencer summarises, in a more or less popular form, in this part of the report, the work accomplished, and gives a good idea of the nature of the country through which the expedition passed.

\section{Nature of the Country traversed.}

It is usual to speak of the whole interior of Australia as a desert or Eremian country, but Prof. Spencer shows that this name as applied to the whole area is very misleading. It is true that over wide areas extending especially over the western half of the interior there spead out sandhills and flats covered with Mulga scrub or "Porcupine" grass, which may justly be described as desert, but in addition to this there is a vast track of country watered by streams which at varying intervals of time are swollen with heavy floods which spread out over wide tracts, and for a time transform the whole country into a land covered with a luxuriant growth of vegetation. To this part of the continent the name of the Australian Steppes has been applied. The Lower Steppes extend over the area occupied by the great Cretaceous formation with its alternating stony or gibber plains, loamy flats, and low.lying terraced hills capped with Desert Limestone. At Lake Eyre the land is 39 feet below sea-level, and gradually rises to a height of rooo feet at its northern limit. What are termed the Higher Steppes are characterised by high ridges of Ordovician and Pre-Cambrian rocks which stretch across the centre of the continent from east to west for some 400 miles. The average elevation of these Higher Steppes may be taken as about 2000 feet, and above them the higher peaks of the ridges rise for some 2500 feet more.

Prof. Spencer devotes two chapters in his Narrative to the country belonging to the Lower Steppes, two to the Higher Steppes, and one to the Desert Region. The gibber plains to which he refers consist of flat surfaces covered with a layer of purple-brown stones, varying in size from an inch to perhaps a foot in diameter, and all made smooth by the constant wearing away of wind-borne sand-grains. Judging from the description, and the views which jllustrate it, nothing could be more desolate than a gibber plain when everything is bare and dry. Throughout this district the low flat-topped desert hills have a thin capping of hard chalcedonised sandstone, and it is by the disintegration of this rock that the gibbers or stones have been produced. The stony gibber plains merge constantly into loamy plains covered with poor scrub, but on which the gibbers are wanting. It is suggested that these loamy plains occupy areas on which the Upper Cretaceous rocks are not capped with the hard chalcedonised Desert Sandstone, and where, therefore, no gibbers have been formed.

\section{Colours of Animals.}

Some interesting remarks are made by Prof. Spencer on the subject of protective colouration. Prof. Spencer has collected animals in Central Australia, both in the dry season and in the NO. I 4 I 7, VOL. 55] 
wet season, and his study of the fauna leads him to the following conclusions,

(I) That in the dry season, when food is scarce and the sum total of activities is at its lowest point, the various animals, such as frogs and lizards, are dull-coloured, but that this dull colouration has not of necessity (as in the case of Amphibolorus barbatus) any definite relation to the environment, though it is often in general accord with it. (2) That in the rainy season, when food is plentiful and the sum total of the activities is at the highest point, various animals are highly coloured, but that this often brilliant colouration has nothing to do either with choice of partners (reaching its climax after pairing has taken place) or with protective colouration-sometimes even it renders the animal more conspicuous.

Limits of space prevent us from summarising any other points of interest from Prof. Spencer's most attractive Narrative. For a more detailed notice of the zoological collections and conclusions, we must refer our readers to the review which appeared in these columns last July (vol. liv. p. 24I). We must mention, however, that the narrative is illustrated by eleven plates (splendidly reproduced from photographs) and seven figures in the text. Among the objects and views depicted upon the plates is a striking natural pillar of sandstone-Chamber Pillar-rising solitary among the sandhills ; Ayers' Rock-a huge dome-shaped monolith, brilliant Venetian red in colour, and one of the most striking objects in Central Australia; several wonderful gorges among the McDonnell Range and Mount Olga. These picturesque views add to the interest of a well-written narrative.

\section{General Geological Features.}

We come now to the part of the Report referring to the geological and botanical results of the expedition, and here again we think that the valuable work accomplished will be best made known by summarising the leading features. The first section of the third volume opens with a general outline of he physical geography of Central Australia, by Prof. Ralph Tate and Mr. J. A. Watt. The subject is dealt with under seven heads, viz. mountains, rivers, gorges and gaps, lakes, claypans, stony plains, and sandhills. The same authors contribute a description of the geological features of the portion of Central Australia examined by them, embracing the country lying between Oodnadatta on the south, and the McDonnell Ranges on the north.

Under headings bearing the names of the geological systems to which the different series of rocks are assigned, an account is given of the general geological features, the extent, thickness, mineralogical composition, petrological characters, and fossiliferous contents of the various rocks. Beginning with the PreCambrian system, the conclusions of previous observers as to the age of the rocks of the McDonnell Ranges, which exhibit a high degree of metamorphism, are summarised. These rocks have been described as Archæean and Azoic, but the authors conclude from the fact that a very strong unconformity separates the rocks from the Lower Silurian Group, that they must be either Cambrian or Pre-Cambrian, and reasons are given for favouring the latter alternative. The evidence obtained points to much of the metamorphic group having had an eruptive origin, whereas the Cambrian rocks of Australia, so far as at present known, are entirely sedimentary. In the region examined (from Oodnadatta to the McDonnell Ranges) Cambrian rocks are held not to be represented. Almost all the strata lying between Mount Burrell Cattle Station on the south, and the McDonnell Ranges on the north, are included by the avthors in the Ordovician system.

The superstructure of the lowest levels around Lake Eyre have long been known to be argillaceous, and to contain marine fossils, as at Mount Margaret, Primrose Springs, and Dalhousie. The fauna was at first referred to the Jurassic period, but has in late years been recognised as contemporaneous with that of the Rolling Downs series, regarded as Upper Cretaceous, of Queensland. It has generally been held that the source of supply of the natural artesian wells on the west side of Lake Eyre was derived from tropical rains in Queensland absorbed by Cretaceous outcrops, and that the issue of these waters was along the line of junction of the Cretaceous water-bearing beds with the Palzozoic rocks on the west margin of Lake Eyre. But the now-ascertained far-northerly extension of the Cretaceous rocks, and the replacement of the prevailing argillaceous condition by sandy strata towards the northern boundary make it probable that the source is, after all, of local origin. Thus, the Finke River from Henbury to Crown Point flows approximately along the.junction of the Cretaceous arenaceous beds and the impervious Ordovician limestones; so also do the Goyder and Lilla Creeks, particularly towards their sources. Moreover, the Cretaceous beds have in the main a slight southerly inclination. It is, therefore, highly probable that they do absorb some of the flood-waters of those riverchannels, and conduct them to considerable depths in the depressed area margining Lake Eyre; whilst in no instance do the subterranean waters issue at the surface at a level so high as that of their conjectural intake. The phenomenon of extinct mound-springs, as at Dathousie, may be explained by the circumstance of a diminished supply; in other words, that the level of saturation has fallen below the level of discharge as a consequence of the desiccation of the climate since Pliocene times.

A hard flinty quartzite or chalcedonised sandstone, varying up to fifty feet in thickness, forms the topmost bed of the Rolling Down series, and is referred to as the Desert Sandstone. The Rolling Down series is held to be akin to the European Upper Cretaceous, and the Desert Sandstone is designated SupraCretaceous, the palxontological difference between the two being very slight. The Desert Sandstone of Central Australia, on account of its attachment to the Upper Cretaceous, and by the occurrence of marine Moliusca of Cretaceous age (at Lake Frome well-sinkings), is regarded as coeval with the Desert Sandstone of Queensland, which, by its intercalated marine sediments, is proved to be. Cretaceous; though separated unconformably from the Rolling Down series (Upper Cretaceous). The phytiferous beds, which underlie marine Eocene in Victoria and South Australia, and are conformable with them, are con. sidered as Pre-Eocene.

As to the origin of the silicification of the Desert Sandstone, in the first place, the obsidian bombs and agates which occur on the Desert Sandstone plateaus and their slopes could not have been transported there by water, unless in the form of ice (an hypothesis incompatible with the coordinate features). The origin of the Desert Sandstone breccia was certainly not due to fracture of the original bed by failure of support arising from denuding action, but might have been caused by a lavaflow or the deposition of highly-heated volcanic ashes when saturated with water. The obsidian bombs demand volcanic action, and agates are not infrequently associated with volcanic ejectamenta ; whilst the silicates of the ash-beds or lava under chemical action would furnish silicated waters as a source of the chalcedonising action on the underlying rock-surfaces. The development of agates within the volcanic material was only another phase of siliceous precipitation. Of this suppositious volcanic formation all that remains are the agates and the obsidian bombs. The theory may seem wild, because of the widespread silicification, and the absence over its area of any traces of actual volcanic outbursts; nevertheless, it is held that no other explanation accounting for the several phenomena appears admissible.

Excepting the silt deposits of the present water-ways and the widespread sand-plains, the only Tertiary deposits of any significance are those which indicate a former water-flow of vaster volumes than at present. These signs are chiefly in the form of gravels, more or less consolidated, through which the present water-channels have cut their way, or in the form of terraces margining the valley-plains through which now flow relatively diminutive creeks. These facts demonstrate that high pluvial conditions once prevailed; and, in consequence, perennial flows in the river-channels of this region were maintained, which, discharging into Lake Eyre, and supplemented by an Artesian supply in and around it, produced an inland sea of fresh water, inhabited by alligators (Pallimnarihus pollens) and turtles, and on its marshy margin dwelt Diprotodon and its fossil associates. Inferentially the date of formation of these gravels and riverterraces is coeval with the existence of Diprotodon, whose extinction was due to those physical causes which destroyed its habitats, and gave Central Australia its present rigorously dry climate. The marsupial life of this period, on comparison with that which replaced it, indicates a high antiquity in the number of extinct genera, and the very high percentage of extinct species.

Gold in the McDonnell Ranges.

The highly metamorphic character of the Pre-Cambrian rocks of the McDonnell Ranges, their greatly disturbed state, their extensive development, and, lastly, the presence of numerous No. 1417 , vol. 55] 
intrusive masses varying much in composition, are all circumstances favourable to the development of mineral deposits in them. Gold is the only mineral that has been found in payable quantities in these ranges, and that only in a very limited area of about fifty square miles, situated seventy to eighty miles E.N.E. of Alice Springs, on the Arltunga or Paddy's Hole goldfield. Although, as just stated, gold in payable quantities has been found on the above-mentioned goldfield, yet alluvial gold in small quantities has been found also near Winnecke's Depôt, Bald Hill, and in some of the gullies in the Georgina Range.

The most important auriferous quartz reefs have a prevailing due north and south trend, and their gold contents show a remarkable uniformity. The country-rock includes metamorphic gneisses and mica schists, intruded by eruptive dykes. Where not absolutely vertical the underlay is almost without exception to the west, and varies from $5^{\circ}$ to $10^{\circ}$. The outcrops of these reefs, which are not, as a rule, traceable for any great distance, vary in width from four inches to two feet six inches, while at the bottom of trenches and shafts the width varies from three inches up to four feet six inches. Taking the average of ten reefs, the width at the surface was found to be twelve inches, while at an average depth of twenty-one feet it was fifteen inches. Gold is contained not only in the veinstone, but occasionally and in a less degree in the selvage also, on one or both sides of the reef. In nearly all the reefs the gold is associated with gossary quartz, some of the best results being obtained from a spongy siliceous matrix, which crumbles easily when subjected to pressure.

The lithological specimens gathered during the Horn Expedition included examples of a number of interesting rocks. The microscopical structure of some of the eruptive, and a few of the most typical of the metamorphic varieties, are briefly described by Mr. W. F. Smeeth and Mr. J. A. Watt, their paper being illustrated by four plates. The Palrontology of the expedition forms the subject of a separate contribution by Prof. Ralph Tate, who also deals with the botany.

\section{Origin of the Flora.}

The route traversed by the main body of the expedition practically circumscribes what has been termed the Larapintine region. The Larapintine flora is fully described, Prof. Tate taking in turn the general physiography and boundaries of the region, botanical characteristics, origin of the fora, previous explorations, enumeration of the flowering plants and vascular cryptogams, and diagnosis of new genus and species. The flora of the central "Eremian region" is briefly described in a separate paper.

The distribution of the constituent elements of the Larapintine flora and their exoteric relationships, taken in conjunction with the physiographic changes that have taken place within the area, lead to the conclusions that :-

(I) The Larapintine table-land was isolated, except perhaps in a northerly direction, during the deposition of the marine sediments constituting the Rolling Downs system (Upper Cretaceous).

(2) The marine submergence was replaced by a lacustrine area during the deposition of the Desert Sandstone (SupraCretaceous).

(3) A cosmopolitan flora prevailed at this period, which continued into Paleocene times.

(4) The area occupied by the lacustrine area of the Desert Sandstone period was somewhat reduced, yet high pluvial conditions continued into Pliocene times.

(5) In Post-Pliocene times a high state of desiccation was reached, which has continued till to-day. The cosmopolitan flora became largely extinct, and its place occupied by an Oriental immigration, more especially over the previously. submerged areas.

A short description, by Mr. J. H. Maiden, of the vegetable exudations collected during the expedition, concludes the volume.

We have had to content ourselves with a sketch of the work of the expedition and of the conclusions arrived at from the knowledge gained. This abridgment will suffice, however, to show the value of the results obtained in geology and botany; and we need only point to the volumes themselves as monuments to Mr. Horn's generosity, and to the industry of the members of the expedition organised by him.

NO. I 4 I 7, VOL. 55]

\section{UNIVERSITY AND EDUCATIONAL} INTELLIGENCE.

The Paris University Council has resolved to consider the institution of a degree which foreign students might take away with them as a proof of their studies and acquirements in Paris.

THE officers for the Oxford University Junior Scientific Club for next term will be as follows:--President: A. W. Brown (Christ Church). Treasurer : A. E. Boycott (Oriel). Editor : A. R. Wilson (Wadham). Chemical Secretary : W. P. Billinghurst (St. John's). Biological Secretary: J. E. H. Sawyer (Christ Church). Committee : R. A. Buddicom (Keble); E. H. Hunt (Balliol); D. Meinertzhagen (New Coll.).

AT the inauguration of the Lyons University, the Rector, $M$. Compayre, announced a donation to the university of $4000 /$. from M. Auguste Falcouz, a Lyons banker. The British Medical Tournal states that the interest of this sum is to be disposed of as follows :- Every two years a prize of $40 /$. sterling will be given to the students of each of the four faculties-literature, science, law, and medicine--who write the best essay on a current subject. The subject of the essay will be chosen by the Council of the Lyons University a year in advance. Every two years instruments for the science and medical faculties will also be bought. When fifty years have elapsed, the Lyons University will have entire control over the capital in order to be able to meet the demands of scientific progress.

DR. G. H. BRYAN, F.R.S., has been appointed professor of pure and applied mathematics in the University College of North Wales, at Bangor. Dr. Bryan graduated at Cambridge in I 886 as Fifth Wrangler. In I 888 he was Smith's Prizeman, his essay being published by the Royal Society; he was then elected Fellow of Peterhouse. In 1895 he became Fellow of the Royal Society, and received the degree of Doctor of Science of Cambridge University. Dr Bryan has been appointed one of the examiners for Part II. of the Mathematical Tripos (1897). $\mathrm{He}$ is the author of a valuable report to the British Association on the "Present State of our Knowledge of Thermodynamics," and of several other important papers on mathematics and mathematical physics.

Magdalen College, Oxford, has just elected Mr. R. W. T. Günther to an official fellowship as tutor in natural science. Mr. Ginther, who is the son of Dr. Albert Günther, F.R.S. so well and long known in the scientific world, has had a distinguished career at Oxford. He was elected to a demyship in natural science at Magdalen in 1888 , from University College School. He took a first class in morphology in 1892, was appointed University student of biology at Naples in 1893, and Royal Geographical student in 1895 , and has been first lecturer and then tutor at Magdalen since I894. He has made several contributions to Prof. Ray lankester's very interesting " Linacre Reports," and he read a paper at the British Association meeting last summer. It may be noted that Magdalen has already this term elected a demy and an exhibitioner in biology, the former coming from the Charterhouse. the latter being a pupil of Prof. Weldon at University College.

THE following are among recent announcements:-Dr. Surmont to be professor of hygiene at Lille; Dr. P. V. Lichtenfels to be full professor of mathematics in the Poly. technic Institute at Graz; Dr. Edler to be associate professor of agriculture in the University of Jena; Dr. E. Pringsheim to a professorship of physics in Berlin University; and Dr. Karl Friedheim to a professorship of chemistry; Dr. Kalischer to be professor of physics at the Technical High School of Berlin. Charlottenburg; Dr. Autenrieth, privat-docent of medical chemistry at Freiburg i. B., to be provisional successor to Prof. Baumanns ; Dr. J. Kurschak to be associate professor of mathematics at the Technical High School in Budapest; Dr. Anton Pestalozzi to be assistant in the Zürich Botanical Museum; Prof. Blass to be full professor of geology at Innsbruck. Dr. Szadeczky has been invited to become associate professor of geology at Klausenburg; and Prof. Allé, professor of mathematics in the German Technical High School at Prague, has been called to the Technical High School at Vienna.

THE conference of headmasters was opened at Rugby on Tuesday, and was largely attended. After a long discussion a resolution declaring the organisation of secondary education to be a matter of pressing necessity, with which the Government should be urged to deal in the next Session of Parliament, was carried, with a rider expressing the desire of the conference to 